\title{
TEORIA CRÍTICA NOS ESTUDOS DAS ORGANIZAÇÕES
}

O professor José Henrique de Faria, da UFPR, selecionou obras de Teoria Crítica para os Estudos Organizacionais. Entre suas próprias contribuições, destaca-se Economia política do poder, em três volumes (Juruá, 2008), sendo um completo estudo teórico-empírico na área. Diferentemente dos estudos críticos [p.e., Critical Management Studies], a Teoria Crítica, objetivando a emancipação do indivíduo, orienta-se pela tradição marxista e psicanalítica, e surge na primeira geração da Escola de Frankfurt e em seus precursores - Lukács, Horkheimer, Adorno, Benjamin, Marcuse e Fromm. Em estudos organizacionais, a Teoria Crítica aparece em João Bernardo, Ricardo Antunes, Harry Bravermann, Fernando Prestes Motta, Frederic Jameson e Maurício Tragtenberg.
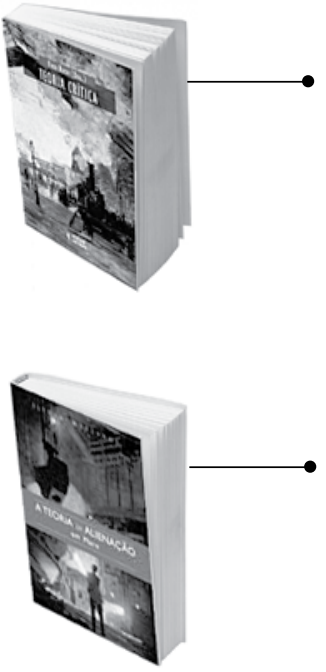

A TEORIA DA ALIENAÇÃO EM MARX. István Mészáros. São Paulo: Boitempo, 2006. 293 p.

Com esse trabalho, Mészáros recebeu o Prêmio Isaac Deutcher e viu seu livro se tornar leitura obrigatória em 15 países de 12 línguas diferentes. Mészáros, buscando inspiração nos Manuscritos de 1844, de Karl Marx, mostra que a alienação é a perda de controle que se materializa em uma força externa que confronta os indivíduos como um poder. O livro é dividido em três grandes partes: "Origens e Estrutura da Teoria Marxiana"; "Aspectos da Alienação"; e "Significação Contemporânea da Teoria da Alienação em Marx".

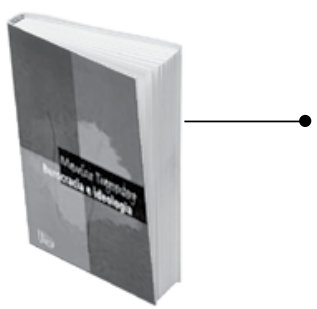

BUROCRACIA E IDEOLOGIA. Maurício Tragtenberg. São Paulo: Unesp, 2008. 288 p.

Nesse livro clássico (a primeira edição é de 1977, pela Ática) de leitura obrigatória para todos os que desejam compreender e Teoria Geral da Administração como uma ideologia, Tragtenberg mostra a administração não como uma técnica neutra de gestão, mas como poder. Maurício Tragtenberg estuda a administração desde a perspectiva da teoria hegeliana do Estado até os sistemas de organização da força de trabalho criados por Taylor e Elton Mayo, estabelecendo uma ligação íntima entre administração de empresas e burocracia estatal. Com isso, Tragtenberg mostra que a administração não é um exercício de harmonia, mas de autoridade.

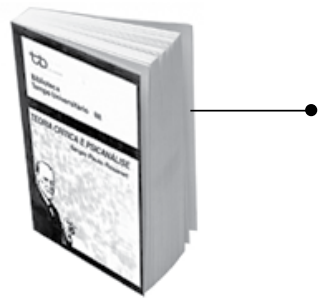

TEORIA CRÍTICA E PSICANÁLISE. Sérgio Paulo Rouanet. 5 ed. Rio de Janeiro: Tempo Brasileiro, 2001. 377 p.

Esse é um texto clássico, cuja primeira edição é de 1978. Nele, Rouanet examina as raízes freudomarxistas em Fromm e Reich, e, em seguida, expõe com clareza a relação da Teoria Crítica com a psicanálise nos trabalhos de Horkheimer, Adorno, Marcuse e Habermas. Rouanet mostra que a psicanálise é, para a Teoria Crítica, simultaneamente objeto e instrumento de crítica. Aqui se pode ver como os teóricos críticos realizaram seus estudos por meio de Freud e contra Freud, e que o freudismo, mais que uma influência para eles, é uma interioridade constitutiva.

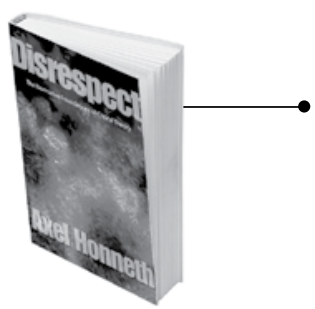

DISRESPECT: The normative foundations of critical theory. Axel Honneth. Cambridge: Polity Press, 2007. 275 p.

Axel Honneth é um filósofo da terceira geração da Teoria Crítica. Esse é o seu mais importante livro, em que ele trata da filosofia social (a partir da patologia do social, da crítica da sociedade, da consciência moral e dominação de classe, e da dinâmica social do desrespeito), da moralidade e do reconhecimento, além dos problemas da filosofia política. Sua área de estudos, já avançada na sociologia do conhecimento, ainda não ganhou espaço nos estudos organizacionais, mas sua provocação está pedindo passagem. 